Proc. Estonian Acad. Sci. Biol. Ecol., 2005, 54, 4, 279-291

\title{
Fridericia eiseni sp. n., a new enchytraeid species close to Fridericia ratzeli (Eisen, 1872)
}

\begin{abstract}
Klára Dózsa-Farkas
Department of Systematic Zoology and Ecology, Eötvös Loránd University, Pázmány Péter sétány 1/C, H-1117 Budapest, Hungary; dfk01@cerberus.elte.hu

Received 12 October 2004, in revised form 1 March 2005

Abstract. Fridericia eiseni sp. n. is described and separated from F. ratzeli (Eisen, 1872) sensu Nielsen \& Christensen 1959. The type material has been collected in Hungary and Estonia. The most characteristic features of the new species are its size (15-19 mm long, $0.4-0.5 \mathrm{~mm}$ wide), the number of segments (49-61), the maximum of 6 chaetae per bundle, and the shape of the spermatheca (the ampulla is surrounded by 8-9 diverticula of different size, the two lateral ones are always larger). The spermathecal ampulla with the diverticula is quite conspicuous, its diameter may reach $200-350 \mu \mathrm{m}$. The ectal duct is long $(400-550 \mu \mathrm{m})$ and relatively slender $(24-26 \mu \mathrm{m})$ with one or two small ectal glands. Three subneural glands are present in XIII-XV. The Estonian material is slightly different from the Hungarian as the maximum number of chaetae is 8 and one specimen also had a different size and segment number ( $24.3 \mathrm{~mm}$ long, $0.55 \mathrm{~mm}$ wide, and 72 segments). However, due to characteristic, common spermatheca, the Estonian individuals are also included in the newly described species.
\end{abstract}

Key words: Oligochaeta, Enchytraeidae, Fridericia, new species, Hungary, Estonia.

\section{INTRODUCTION}

During my sampling in different regions and habitat types in Hungary I found a new enchytraeid species, which resembled mostly to Fridericia ratzeli but had characteristic differences, which also distinguish the two taxa.

Fridericia ratzeli (Eisen, 1872) is a complicated group with different cytotypes and parthenogenetic lineages among sexual species, with highly diverse chromosome numbers as Schmelz (2003) summarized on the basis of Nielsen \& 
Christensen (1959), Nurminen (1970), and Christensen (1961). He grouped 14 synonymous species into $F$. ratzeli, and the character of the species includes all different morphological variants. Two different forms are distinguished, a thinner and smaller, and a thicker and longer variant, which are also partly separated by the shape of the spermatheca and the number of the subneuralis glands. On a similar basis Eisen $(1872,1878,1879)$ himself described two species, $F$. ratzeli (Eisen, 1872) and F.dura (Eisen, 1878), later the second species became the synonym of the first (Michaelsen 1900). Chalupský (1992) tried to restore the second species but it was impossible for two reasons. On the one hand, the coverage of the two names by Chalupský and Eisen is not unequivocal, and on the other hand, as Schmelz (2003) pointed out, the original type material is either lost or contains other species.

Therefore, F. ratzeli in its present form, as it is also indicated by Schmelz (2003), is rather a species complex, which should be divided into several taxa later (maybe mainly using biochemical methods). On this basis I consider $F$. ratzeli as described and drawn by Nielsen \& Christensen (1959), which is nearly identical with the size, chaeta number, and spermatheca shape given by Eisen (1872, 1879), too. In summary, I consider the most important characteristics of $F$. ratzeli (Eisen, 1872) sensu Nielsen \& Christensen the following: 20-30 mm long and about 0.7-1.0 mm thick (Nielsen \& Christensen (1959) characterized this species as "rather short and stout"). The ampulla of spermatheca is usually surrounded by 6-8 (5-10) sessile, globular diverticula with or without sperm. The spermathecal ectal duct is wide. The worm has a subneural gland in XIII. See in greater detail later.

In this paper I describe a new enchytraeid species, F. eiseni $\mathrm{sp}$. n., similar to but distinguishable from $F$. ratzeli. I assign to the new species specimens collected in Estonia in 2004 by participants of the 6th Enchytraeidae Symposium, as well as previously collected individuals, which were misidentified as $F$. sacculata Bell, 1936 (Dózsa-Farkas et al. 1998).

\section{MATERIAL AND METHODS}

The worms were investigated and measured alive or embedded in clove oil after fixation. The important structures were noted, drawn, and photographed with a Zeiss Axioskop 2 microscope, using differential interference contrast (DIC) illumination and an Olympus Colour View digital camera with DP-Soft software. The animals were preserved in $70 \%$ ethanol or Bouin's fluid. Some of them were stained in borax-carmine or orcein in acetic acid. After morphological investigation some specimens were selected for DNA investigation. This examination is still in progress, the results will be published later. 


\section{Fridericia eiseni sp. n.}

Fridericia sacculata Bell, 1936: Dózsa-Farkas et al. 1998

The type material is deposited in the author's (K. Dózsa-Farkas) collection at the Department of Systematic Zoology and Ecology, Eötvös Loránd University, Budapest, in the Hungarian Natural History Museum, Budapest, and Zoologisches Museum der Universität Hamburg.

Holotype: F.12 (1912), Mátra Mountains, coll. K. Dózsa-Farkas

Type locality: Hungary, Mátra Mountains, Markaz, rockery, 4749'50" N, $20^{\circ} 02^{\prime} 52^{\prime \prime}$ E 31.03 .2003

Paratypes: Hungary (coll. K. Dózsa-Farkas; some specimens collected by other people as listed below):

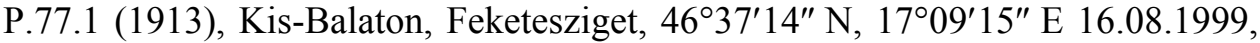
two spms; P.77.2 (1914), Mátra Mountains, Markaz, rockery, 4749'50" N, $20^{\circ} 02^{\prime} 52^{\prime \prime} \mathrm{E}, 285 \mathrm{~m}, 31.03 .2003$, one spm; P.77.3 (1915), Mátra Mountains, Markaz, rockery, $47^{\circ} 51^{\prime} 53^{\prime \prime} \mathrm{N}, 20^{\circ} 03^{\prime} 56^{\prime \prime} \mathrm{E}, 608 \mathrm{~m}, 16.10 .2002$, three spms; P.77.4 (1916), Mátra Mountains, Ilona-völgy, on the bank of a stream, 47 $54^{\prime} 46^{\prime \prime} \mathrm{N}$, 2003'26" E, 16.10.2002, one spm; P.77.5 (1917), Mátra Mountains, Pilisszentistván,

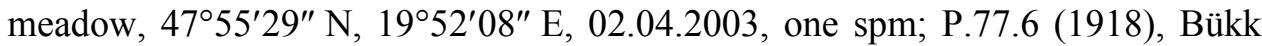
Mountains, Kismezö sink-hole (dolina), under Fagus silvatica, 9-10.05.2001, three spms; P.77.7 (1919), Bükk Mountains, Kismező, sink-hole (dolina), 9-10.05.2001 under Picea abies, one spm; P.77.8 (1920), Bükk Mountains, Kismezö, sink-hole (dolina), 9-10.05.2001, two spms; P.77.9 (1921), Bükk Mountains, 48 $07^{\prime} 37^{\prime \prime} \mathrm{N}, 20^{\circ} 28^{\prime} 27^{\prime \prime} \mathrm{E}$, rockery, 12.10.2003, coll. G. Boross, two

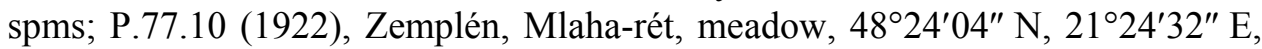
28.05.2003, coll. K. Dózsa-Farkas, \& M. Pobozsny, one spm; P.77.11 (1923), Szamos River, Olcsvai kapu, meadow, 8-10.10.2000, two spms; P.77.12 (1924), Tisza River, Tivadar, under grass, 30.05.2002, two spms; P.77.13 (1925), Tisza River, Szabolcs, meadow, 30.05.2002, four spms (in Hungarian Natural History Museum); P.77.14 (1926), Tokaj, backwater of Tisza River, soil, 27.05.2001, five spms; P.77.15 (1927), Fertő-Hanság National Park, Lébény, Tárnokréti way, meadow, 47 $44^{\prime} 27^{\prime \prime}$ N, $17^{\circ} 20^{\prime} 34^{\prime \prime}$ E, 18.10.2000, four spms (in Hungarian Natural History Museum); P.77.16 (1928), Fertő-Hanság National Park, Csorna, under grass, $47^{\circ} 42^{\prime} 04^{\prime \prime} \mathrm{N}, 17^{\circ} 03^{\prime} 04^{\prime \prime} \mathrm{E}, 18.10 .2000$, one spm; Ol 14551, Bükk Mountains, Kismezö, sink-hole (dolina), 9-10.05.2001, two spms (in Zoologisches Museum der Universität Hamburg).

Estonia: O1 14552, near Võrtsjärv Limnological Station, L-4, orchard, Petseri group of the Station's dwelling-houses, grass sod with sandy soil, 15-19.05.2004, coll. participants of 6th Enchytracidae Symposium, one spm (in Zoologisches Museum der Universität Hamburg); P.77.18a and b (1930), Võrtsjärv Limnological Station, mixed forest of Picea abies and Betula verrucosa, 21.06.1996, coll. T. Timm, two stained slides in Euparal of a dissected and disjointed specimen. Etymology: Named in honour of Gustav Eisen. 


\section{Description}

Large worm, length $15-19 \mathrm{~mm}$. Diameter $0.4-0.5 \mathrm{~mm}$. Segment number 49-61 (one specimen from Estonia, however, was substantially larger (length $24.3 \mathrm{~mm}$, diameter $0.55 \mathrm{~mm}$ in preserved state, segment number $76 / \mathrm{Ol} 14552 /$ ). Chaetae as maximum 6 per bundle, formula according to Nielsen \& Christensen (1959): $\underline{4,5}, 6-5,4,3,2: 4,5, \underline{6},-6,5,4,3,2$ (the most common numbers of chaetae are underlined). Only in specimens from Estonia I observed up to 8 chaetae per bundle. Outer chaetae much longer than inner, e.g. outer $71 \mu \mathrm{m}$, inner $38 \mu \mathrm{m}$ long in a bundle. Epidermal gland cells in 3-4 or rows on the preclitellar segments. Body wall of medium thickness (about $33 \mu \mathrm{m}$ ), cuticle thin. Dorsal pores beginning from VII. Brain egg-shaped, 1.5 times longer than wide (about $160 \mu \mathrm{m}$ long). Oesophageal appendages (peptonephridia) much branched, c-type. Pharyngeal glands (septal glands) all with ventral lobes, dorsal connection wide in IV, narrow in $\mathrm{V}$ and in VI (Fig. 1). Nephridia as 5 preclitellar pairs from $6 / 7$ to $9 / 10$, length ratio of ante- and postseptale about $1: 1.5$, medial origin of efferent duct. Chloragocytes beginning with segment $\mathrm{V}$, forming denser layer from VI, containing brown granules. Coelomocytes numerous, mucocytes $30 \mu \mathrm{m}$, a-type (according to Möller 1971), lenticytes

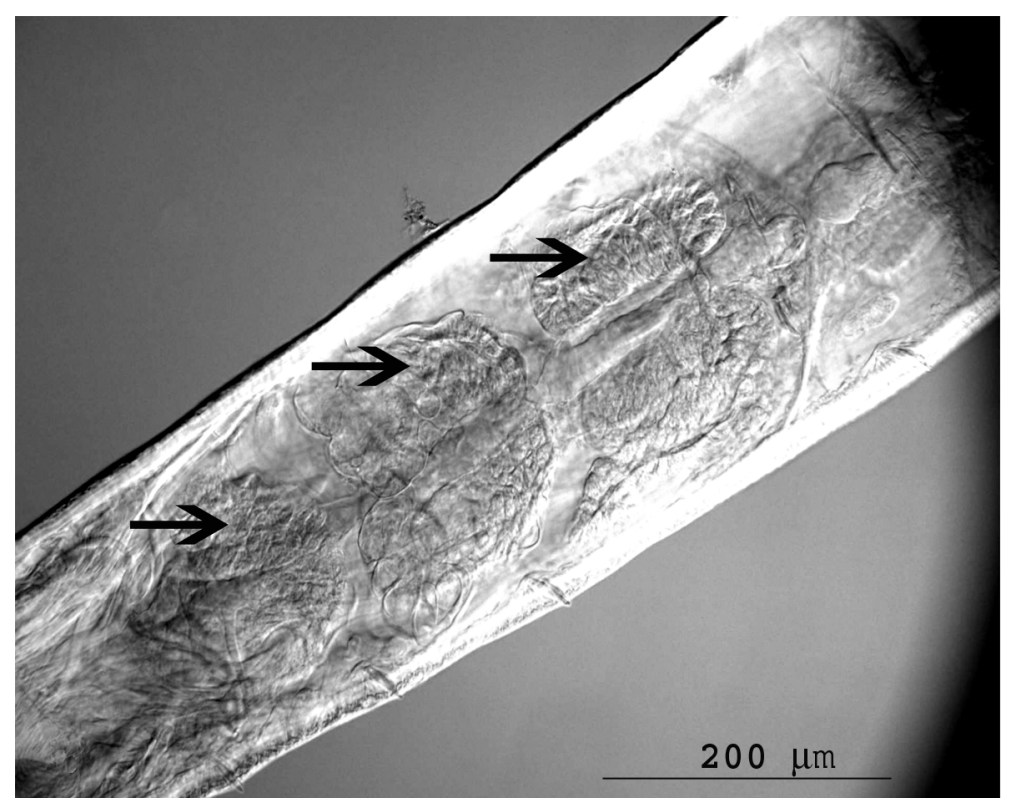

Fig. 1. Fridericia eiseni sp. n. Pharyngeal glands. Photograph from the preserved holotype. 
small, 5-10 $\mu \mathrm{m}$ long. Chylus cells in XVI-XVII. Dorsal blood vessel from XVIII-XXI. Clitellum girdle-shaped, gland cells in dense rows, hyalocytes and granulocytes (Fig. 2). Seminal vesicle conspicuous, brownish, occupying 2-3 segments (X-XI or X-XII). Sperm funnel 3-4 times as long as wide, almost as long as or $2 / 3$ of the body diameter, collar distinct, as wide as funnel body (Fig. 3). Spermatozoa about $350 \mu \mathrm{m}$ long. Male copulatory organ medium sized (e.g., $170 \mu \mathrm{m}$ long $\times 100 \mu \mathrm{m}$ wide $\times 80 \mu \mathrm{m}$ high) (Fig. 4), bursal slit Tshaped (Fig. 5). Subneural glands (Fig. 6) in XIII-XIV-XV (largest in XIII, width $90 \mu \mathrm{m}$ ). Spermatheca (Table 1). One (sometimes two) small (about $30 \mu \mathrm{m})$, pear-shaped ectal gland present. Ectal duct long $(400-550 \mu \mathrm{m})$ and $24-26 \mu \mathrm{m}$ wide. Ampulla (Fig. 7) is surrounded distally by $8-9$ diverticula of various size, the smallest ones about $30-37 \mu \mathrm{m}$ long, the two lateral ones always larger, about $80-120 \mu \mathrm{m}$. Sperm located in the distal part of the lumen of the ampulla, surrounding the ental bulb in a thick circle. The two spermathecae along with the ampullae quite conspicuous, not arranged next to each other dorsally. The diameter of the organ may reach $200-350 \mu \mathrm{m}$. The proximal part of ampulla short. Separate openings into oesophagus. One to three mature eggs present at a time.

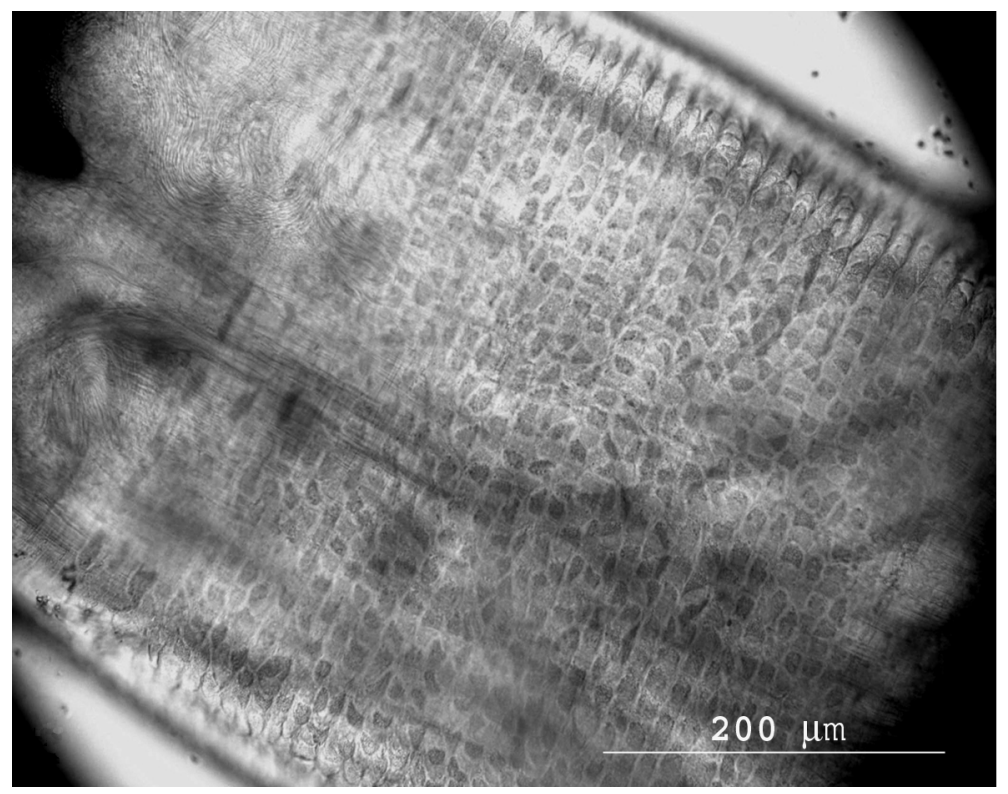

Fig. 2. Fridericia eiseni sp. n. Clitellar glands, dorsal view. Photograph from a living specimen. 


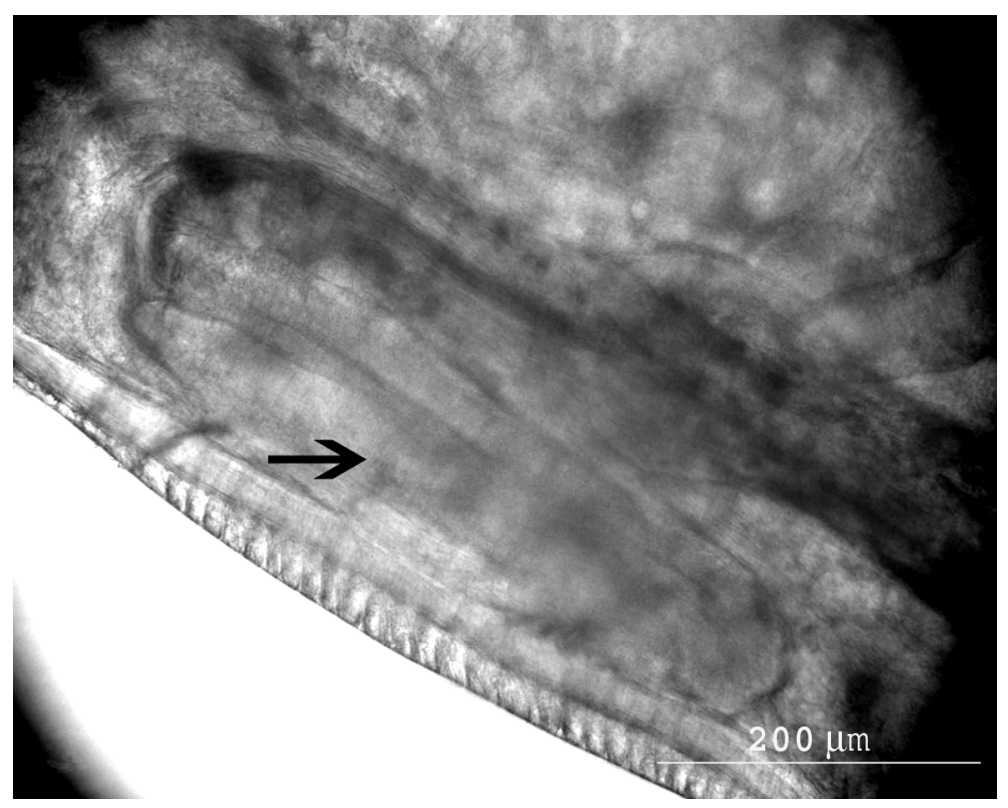

Fig. 3. Fridericia eiseni sp. n. Sperm funnel. Photograph from a living specimen.

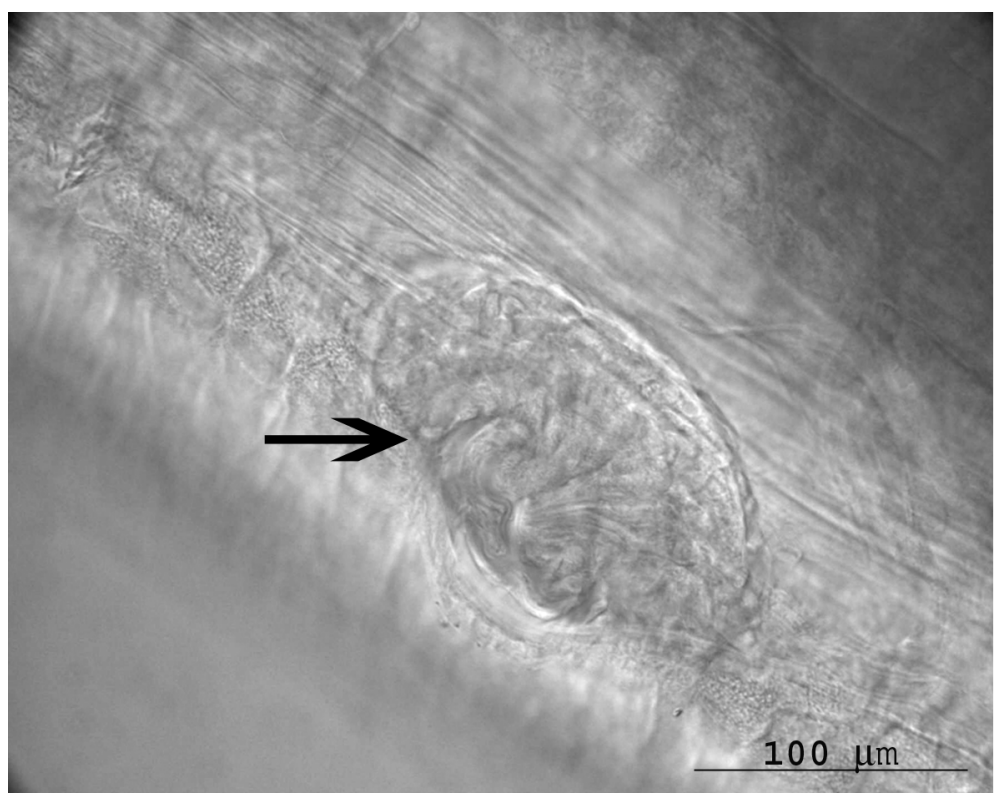

Fig. 4. Fridericia eiseni sp. n. Penial bulb. Photograph from the preserved holotype. 


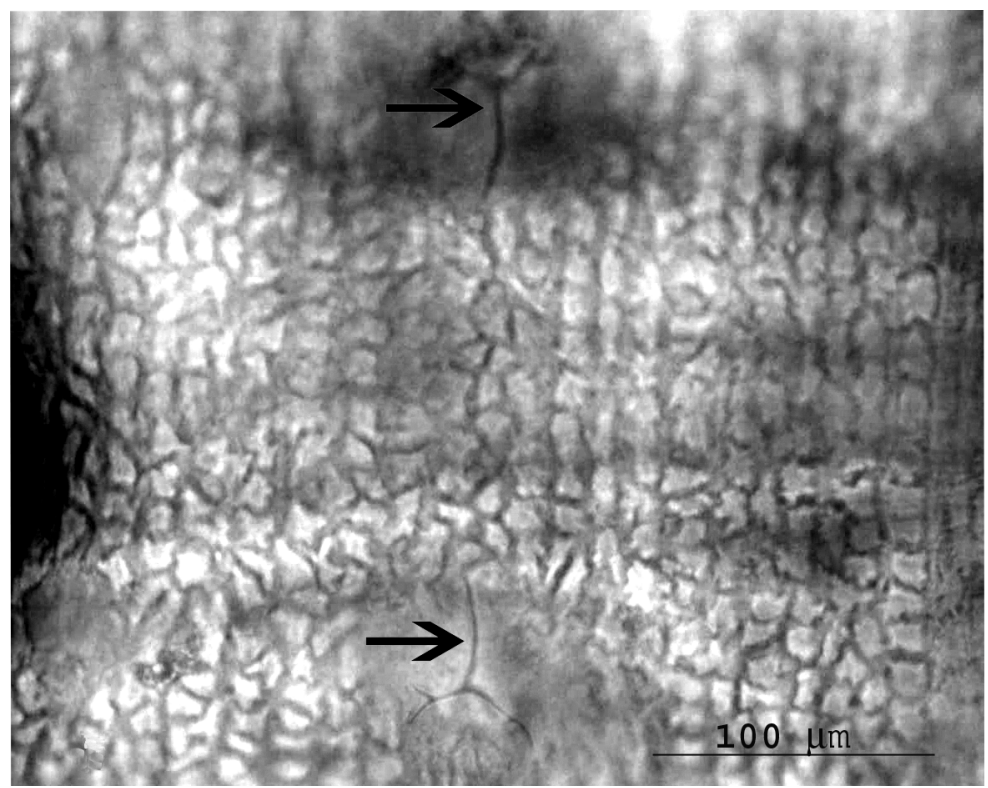

Fig. 5. Fridericia eiseni sp. n. Bursal slits of the male copulatory organs, ventral view. Photograph from a living specimen.

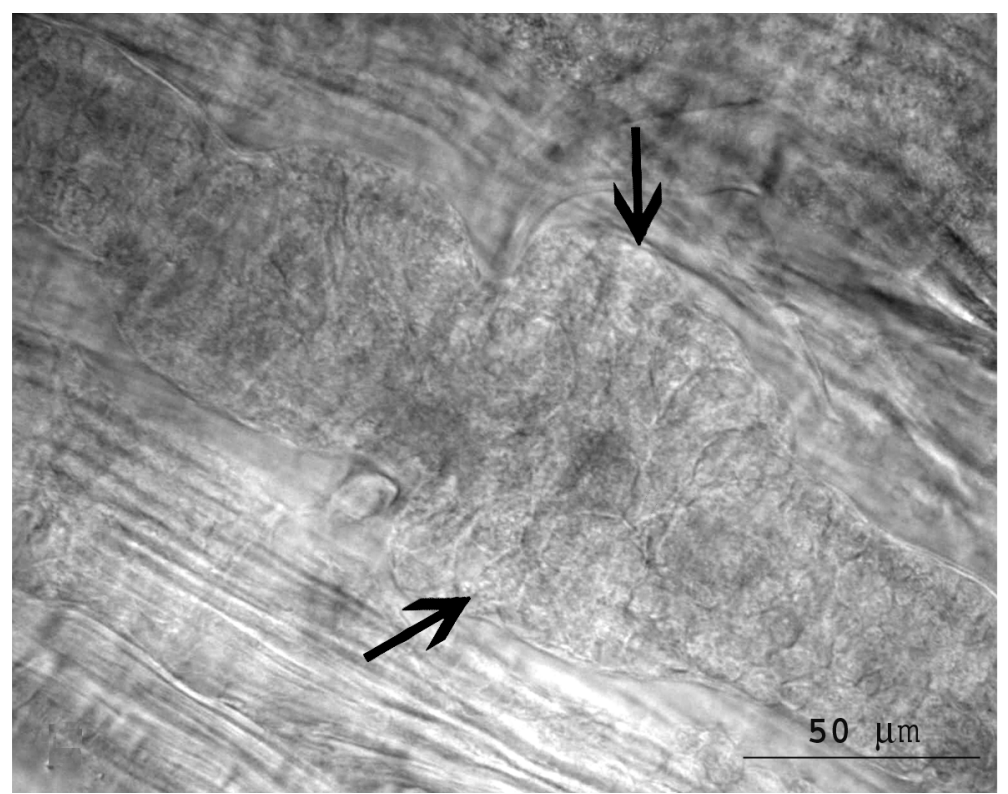

Fig. 6. Fridericia eiseni sp. n. A subneural gland in XIV. Photograph from the preserved holotype. 


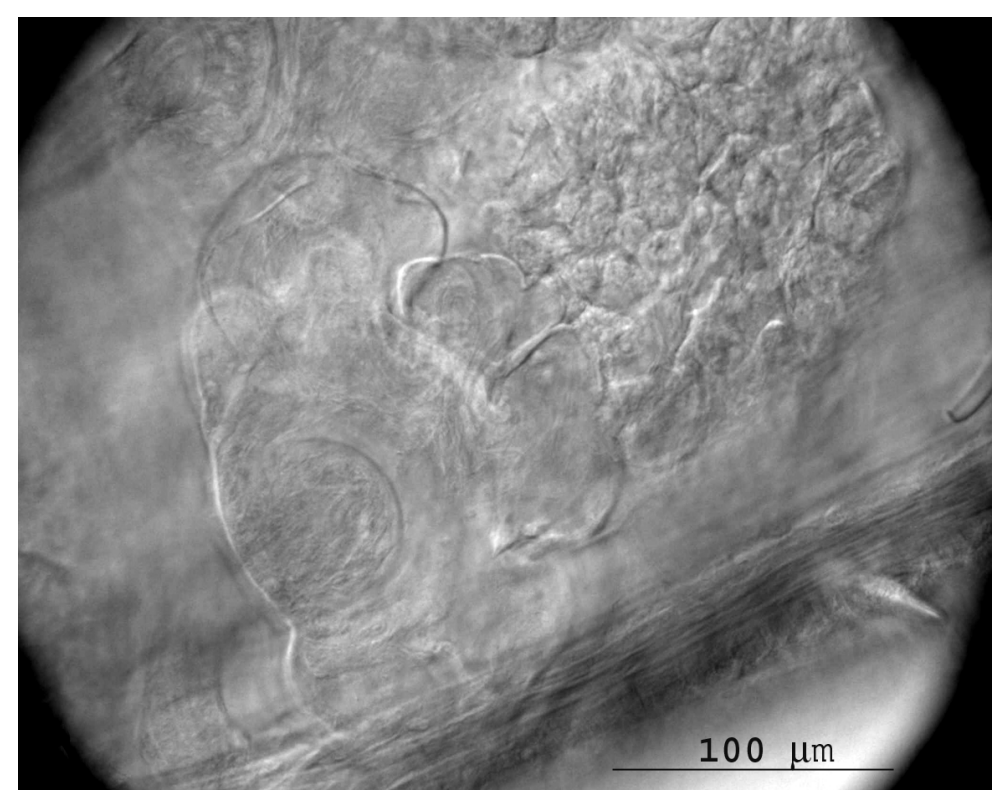

Fig. 7. Fridericia eiseni sp. n. Spermatheca. Photograph from the preserved holotype.

\section{Diagnosis}

The species can be recognized by the following combination of characters: (1) the size of worms $(15-19 \mathrm{~mm}$ long and $0.4-0.5 \mathrm{~mm}$ wide, the number of segments is between 49 and 61); (2) the size and form of spermatheca: diameter of the ampulla with the different diverticula (the two lateral ones are always larger) may reach $200-350 \mu \mathrm{m}$, long $(400-550 \mu \mathrm{m})$ and relatively thin $(24-26 \mu \mathrm{m})$ ectal duct with one or two small ectal glands; (3) maximum six chaetae per bundle (but eight in the Estonian population); (4) c-type of oesophageal appendages; (5) clitellar glands in dense rows; (6) large seminal vesicle, occupying 2-3 segments;

(7) T-shaped penial slit; and (8) three subneural glands in XIII-XV.

\section{Remarks}

The new species is most similar to F. ratzeli (Eisen, 1872) sensu Nielsen \& Christensen (1959). Similarities and differences are summarized in Table 1. Both species have the same number of segments, but F. eiseni is smaller and thinner (except for one Estonian specimen, $\mathrm{Ol} 14552$ ) and the number of chaetae does not exceed six (except for specimens of Estonia). Even if the individuals from Estonia have a higher number of chaetae and one specimen was much longer, the 
Table 1. Comparison of Fridericia eiseni sp. n. and Fridericia ratzeli sensu Nielsen \& Christensen (1959) $(*$ data of one specimen from Estonia, ** data from Estonian specimens)

\begin{tabular}{|c|c|c|}
\hline & F. ratzeli (Eisen, 1872) & F. eiseni sp. n. \\
\hline Length/diameter, mm & $(15)-20-30-(35) / 0.7-1$ & $15-19 / 0.4-0.5\left(24.4 / 0.55^{*}\right)$ \\
\hline Segments & $(38)-50-60-(70)$ & $49-61\left(76^{*}\right)$ \\
\hline Max chaetae & $6-8(9)$ or 6 & 6 or $8 * *$ \\
\hline Oesophageal appendages & c-type & c-type \\
\hline $\begin{array}{l}\text { Number of preclitellar } \\
\text { nephridia }\end{array}$ & 5 pairs & 5 pairs \\
\hline Origin of dorsal vessel & XVII-XX & XVIII-XXI \\
\hline Coelomo-mucocytes & a/c-type $(40-60 \mu \mathrm{m})$ & a-type $(30 \mu \mathrm{m})$ \\
\hline Lenticytes & Numerous, small & Numerous, small \\
\hline Chylus cells & $?$ & XVI-XVII \\
\hline Clitellum & $\begin{array}{l}\text { Girdle-shaped, gland cells } \\
\text { irregularly arranged }\end{array}$ & $\begin{array}{l}\text { Girdle-shaped, gland cells } \\
\text { in rows }\end{array}$ \\
\hline Bursal slit & Longitudinal slightly bent & T-shaped \\
\hline Subneural glands & In XIII (or absent) & In XIII-XIV-XV \\
\hline Seminal vesicle & Varies in development & Large into $\mathrm{X}$ \\
\hline Sperm funnel & $250-500 \mu \mathrm{m}$ long & $400-500 \mu \mathrm{m}$ long \\
\hline
\end{tabular}

Spermatheca
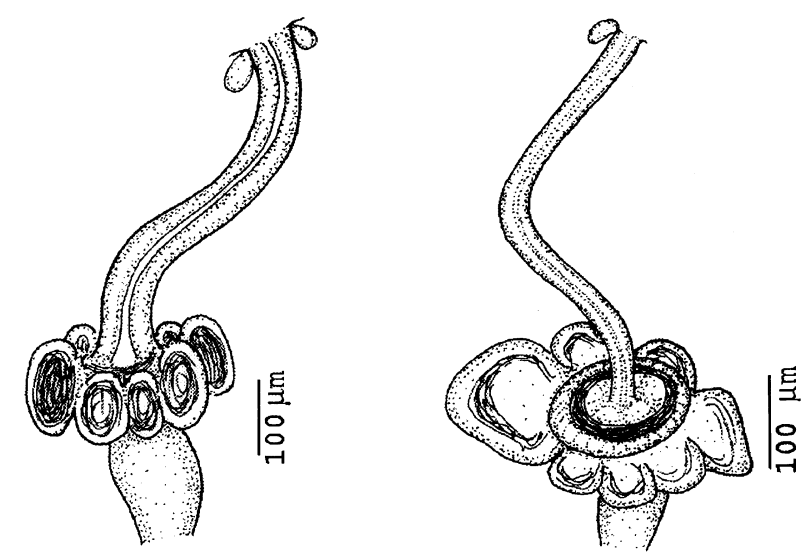
characteristic shape of the spermatheca makes me believe that they belong to the same species (F. eiseni). Whether the Estonian populations form a separate subspecies may be resolved by future DNA studies. Nevertheless, F. ratzeli specimens may also have at the most six chaetae, even within the same population. By virtue of my observations I think that this number may depend on the age of the specimen. The main differences are in the spermathecae. Both species possess an ectal duct of similar length $(400-550 \mu \mathrm{m}$ long), but that of $F$. ratzeli is much wider $(60 \mu \mathrm{m})$ and widens proximally (to $70 \mu \mathrm{m})$. Contrary to this, in $F$. eiseni the diameter of the duct is $24-26 \mu \mathrm{m}$ only. The ampulla of the spermatheca in $F$. ratzeli is surrounded distally by five to ten sessile, more or less globular diverticula (sometimes variable in size), with a large lumen filled with sperm or not. The diameter of this distal part of the ampulla together with the diverticula totals up to approximately $200-250 \mu \mathrm{m}$ (Fig. 8). In F. eiseni, the ampulla is similarly surrounded distally by eight to nine diverticula, which, however, are of different size, the two lateral ones are always larger. The ampulla of the spermatheca with the diverticula is quite conspicuous. The diameter of the organ may reach $210-350 \mu \mathrm{m}$. The location of the clitellar glands is somewhat divergent, gland cells are in dense rows in F. eiseni (Fig. 2) and irregularly arranged in F. ratzeli (Fig. 9). The shape of the male bursal slit is also different: (T-shaped in $F$. eiseni (Fig. 5) and longitudinal, slighly bent in F. ratzeli (Fig. 10).

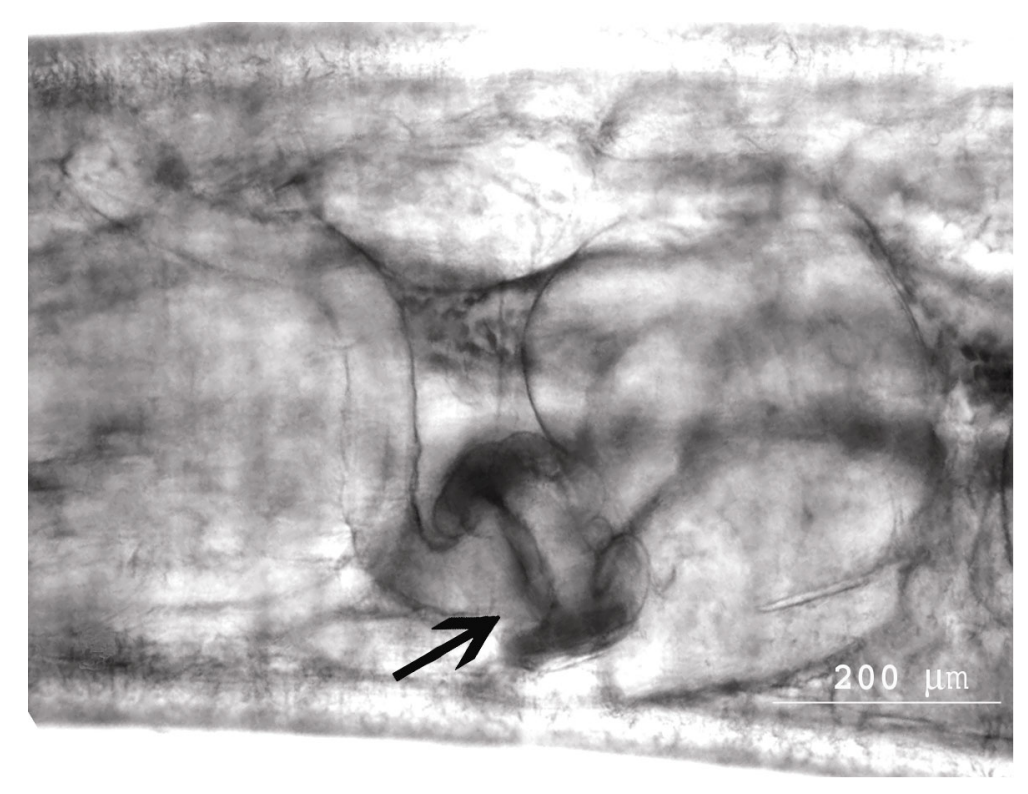

Fig. 8. Fridericia ratzeli. Spermatheca. Photograph from a living specimen. 


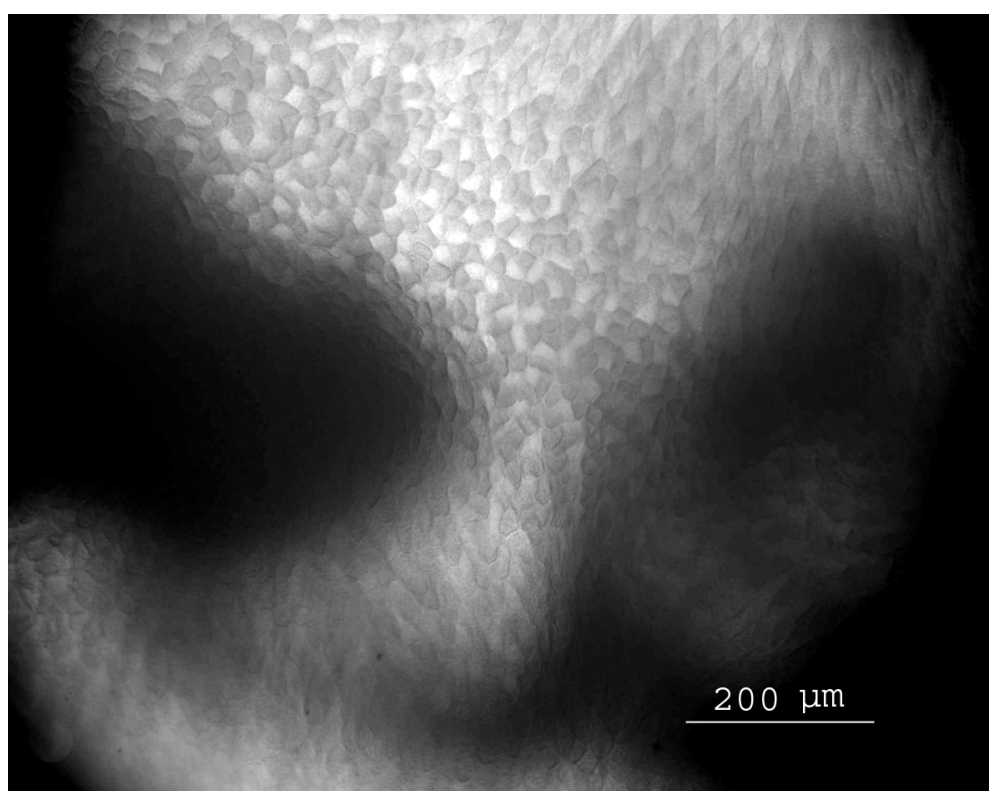

Fig. 9. Fridericia ratzeli. Clitellar glands, dorsal view. Photograph from a living specimen.

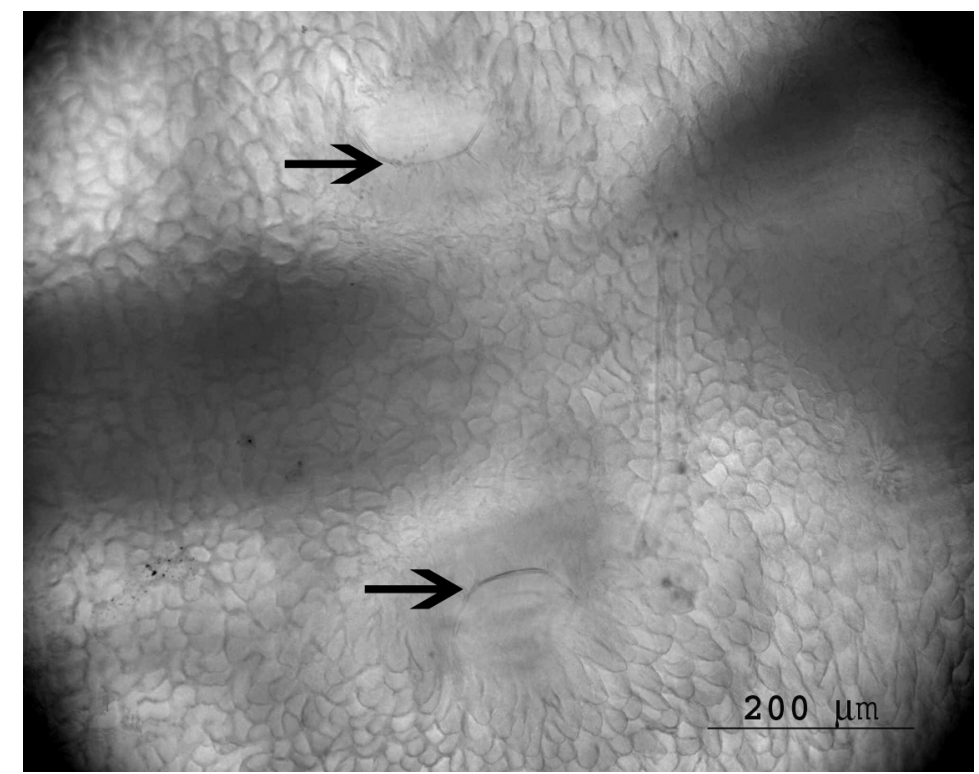

Fig. 10. Fridericia ratzeli. Bursal slit of the male copulatory organs, ventral view. Photograph from a living specimen. 
Large Fridericia species with similar spermathecae (F. agilis Smith, 1895; F. agricola Moore, 1895; F. firma Smith \& Welch, 1913; F. oconeensis Welch, $1914)$ are different from the new species by the absence of the subneural gland(s). Besides, the maximum diameter of the ampulla of the spermatheca and the diverticula is only $110 \mu \mathrm{m}$ in $F$. oconeensis, $220 \mu \mathrm{m}$ in $F$. firma and there is no spermathecal ectal gland. The diameter of the same organ is smaller $(150-180 \mu \mathrm{m})$ again in F. agricola and the maximum chaetal number is four, occasionally three or five per bundle. F. agilis also has a lower maximal chaetal number (four). Finally, F. regularis (Nielsen \& Christensen, 1959), though having no subneural glands, has a thickened epidermal glandular region ventrally in XIV, and b-type oesophageal appendages, which are its other important distinguishing characteristic.

I do not want to compare the new species with the synonyms summarized by Schmelz (2003) because, as discussed before, it is a complicated species complex and its separation needs further studies.

Occurrence: Found mostly in wet soils of forest or grassland.

Distribution:

Hungary: Several finds of Bükk, Mátra, and Zemplén Montains, Kis-Balaton and Fertö-Hanság National Park (marsh-land), on the bank of Tisza and Szamos rivers and Egervíz stream.

Estonia: Võrtsjärv Limnological Station, orchard, grass sod with sandy soil.

\section{ACKNOWLEDGEMENTS}

This research was financed by the Hungarian National Scientific Research Foundation (OTKA 034864). Some instruments (microscope and digital camera) were also provided by the OTKA Foundation (M 27225 and M 045482). I thank Dr Tarmo Timm (Tartu, Võrtsjärv Limnological Station) for his help in the collection of the Estonian material.

\section{REFERENCES}

Chalupský, J. 1992. Terrestrial Enchytraeidae (Oligochaeta) and Parergodrilidae (Polychaeta) from Sweden, with description of a new enchytraeid species. Zool. Scr., 21, 133-150.

Christensen, B. 1961. Studies on cyto-taxonomy and reproduction in the Enchytraeidae. Hereditas, 47, 387-449.

Dózsa-Farkas, K., Healy, B., Rota, E. \& Timm, T. 1998. Estonian Enchytraeidae (Oligochaeta) 1. Terrestrial Enchytraeidae from the Võrtsjärv Limnological Station and from Puurmani. Proc. Estonian Acad. Sci. Biol. Ecol., 47, 235-247.

Eisen, G. 1872. Om några arktiska oligochaeter. Öfv. Kongl. Vetenskaps-Akad. Förh., 1, 119-124.

Eisen, G. 1878. Redogörelse för Oligochaeter samlade under de Svenska expeditionerna till Arktiska trakter. Öfv. Akad. Förh., 3, 63-69.

Eisen, G. 1879. On the Oligochaeta collected during the Swedish expeditions to the arctic regions in the years 1870, 1875 and 1876. Kong. Sv. Vet.-Akad. Handl., 15(7), 10-49. 
Michaelsen, W. 1900. Oligochaeta. Das Tierreich. Vermes, 10 (Schulze, F. E. \& Spengel, J. W., eds.). R. Friedländer, Berlin.

Möller, F. 1971. Systematische Untersuchungen an terricolen Enchytraeiden einiger Grünlandstandorte im Bezirk Potsdam. Mitt. Zool. Mus. Berlin, 47, 131-167.

Nielsen, C. O. \& Christensen, B. 1959. The Enchytraeidae. Critical revision and taxonomy of European species (studies on Enchytraeidae VII). Nat. Jutl., 8-9.

Nurminen, M. 1970. Records of Enchytraeidae (Oligochaeta) from the west coast of Greenland. Ann. Zool. Fenn., 7, 199-209.

Schmelz, R. M. 2003. Taxonomy of Fridericia (Oligochaeta, Enchytraeidae). Revision of species with morphological and biochemical methods. Abh. Naturwiss. Ver. Hamburg (NF), 38.

\section{Uus valgeliimuklaste liik Fridericia eiseni sp. n. rühmast Fridericia ratzeli}

\section{Klára Dózsa-Farkas}

Koondliigist Fridericia ratzeli on eraldatud teadusele uus liik Fridericia eiseni. Materjal pärineb Ungarist ja Eestist. Uus liik erineb teistest kõige rohkem seemnehoidla suuruse ja kuju poolest. 